\title{
CORRALLING CONFLICT: The Politics of Australian Federal Heritage Legislation SINCE THE 1970S
}

\author{
PAUL ASHTON AND JENNIFER CORNWALL
}

Public History Review, Vol 13, 2006, pp53-65

I n August 1968, conservative National Party leader Joh Bjelke-Petersen became Premier of the state of Queensland. He referred to conservationists as these 'subversives, these friends of the dirt'. ${ }^{1}$ A generation later, few if any Australian politicians would have publicly attacked the environment and its supporters for fear of electoral damage. After years of major environmental battles which on occasion determined the fate of some governments, the environment had crashed through into mainstream politics. ${ }^{2}$ Natural and cultural heritage was firmly on local, state and federal political agendas. In the lead up to the 1996 national election Prime Minister John Howard, the first Australian politician to openly label himself a conservative, announced that 'We're all greenies now'.

While highlighting the political importance of heritage and the environment, this was in part an attempt to reassure concerned voters that the states and territories adequately protected heritage places and values as the Howard government moved to 'rationalise' federal heritage legislation. Institutionally, at federal and state levels, a process commenced in the early 1990s of devolving responsibility for the identification, preservation and interpretation of sites and objects of cultural and natural significance to local government. ${ }^{4}$ Localities became the site for heritage frontiers that ebb and flow as different groups assert their environmental agendas. The 'local' is also the most flexible arena in which to accommodate differences - thus devolution of heritage responsibilities - and to manage conflict. The broad range of interest groups and cultures in Australia makes it extremely difficult to manage such clashes at regional let alone state or national levels. (There are over 100 nationalities represented in Australia.) State and federal politicians were simultaneously and respectively once or twice removed from political heat generated by contestation.

Heritage in Australia was also, by the 1990s, a substantial, multifaceted industry. Cultural and eco tourism generated a significant proportion of the country's gross domestic product. ${ }^{5}$ Along side and partially in response to industry, a heritage bureaucracy had developed. The corporatisation of heritage saw the rise in the 
1980s and 1990s of a new generation of heritage professionals who attempted with varying degrees of success to place heritage assessment on a quasi-scientific footing. Perhaps their greatest achievement, in terms of cultural heritage, was gaining recognition in the 1990s for the vital importance of intangible heritage. ${ }^{6}$ Intangible heritage, or social value, inscribes objects and sites that cannot speak for themselves with cultural and social meanings. Since the 1980s, some more radical practitioners had been working to counteract the dominance of tangible remains of the past in determining cultural significance. ${ }^{7}$ This victory over empiricism, however, was in some respects to prove pyrrhic.

On 25 October 2002, the Federal Shadow Minister for Heritage and the Environment, Kelvin Thomson, issued a press release concerning proposed legislation put forward by the Howard Government to drastically recast the Australian Heritage Commission (AHC). This move, Thomson warned, would, among other things, 'downgrade the Australian Heritage Commission to an advisory council with limited functions' and provide circumscribed protection to "values of place", rather than protecting the place itself'. Thus, after almost thirty years of Commission activity, a significant amount of which strove, from the late 1980s, for recognition of 'social value' or 'sense of place' conservatives seemingly succeeded in subverting cuttingedge Australian heritage practice. Critics of the Government forecast historic markers without buildings, historic lookouts without landscapes and sites of community without people. The bleakest scenario saw nothing but memories left at the end of the day.

For some time, too, heritage was operating in a relatively new, semi-official, reactionary paradigm. Cultural pluralism was promoted as a national historical frame in the lead up to the 1988 Bicentenary. But this was resisted by the political right. Conservatives had reacted to the suggested bicentennial theme, 'Living Together', arguing for 'The Australian Achievement' which emphasised 'positive achievements and triumphs over adversity and social problems'. ${ }^{8}$ Coming into office in 1993, the Howard Government also insisted on a celebratory historical perspective, opposed to a so-called 'black armband' history, that told 'the story of [all] our people... broadly constituting a scale of heroic and unique achievement against the odds'. ${ }^{9}$ Howard put it this way in his 1996 Sir Robert Menzies lecture:

This black armband view of our past reflects the belief that most Australian history since 1788 has been little more than a disgraceful story of imperialism, exploitation, racism, sexism and other forms of discrimination.

I take a different view. I believe that the balance sheet of our history is one of heroic achievement and that we have achieved much more as a nation of which we can be proud than of which we should be ashamed. ${ }^{10}$

Heated debate over the Australian story portrayed in the National Museum of Australia from its opening in 2001 for the centenary of Federation centered essentially around its deviation from the government's preferred saga of progress. ${ }^{11}$ 
Heritage conservation, as with some other heritage practices, ${ }^{12}$ was by the turn of the twenty-first century institutionally confined in its ability to represent conflict. This article charts the incorporation and corralling of heritage work at the federal level in Australia through a case study of the rise and fall of the Australian Heritage Commission.

\section{The Getting of Heritage}

Before the 1970s, heritage legislation in Australia was generally piecemeal, sporadic, sometimes discretionary and mostly ineffective. Acts passed from the 1890 s to the 1920s were almost exclusively concerned with protecting native flora and fauna, some of which had become state and national symbols. ${ }^{13}$ These were polite neoliberal responses to growing environmental problems caused by clearing and unsustainable farming practices that resulted in massive soil erosion in the 1920s and beyond. ${ }^{14}$ Though some middle-class preservationists, usually unsuccessfully, pressed governments to save cherished homesteads and mansions for future generations, the built environment remained unprotected. ${ }^{15}$

The power of the ideology of 'progress', manifest in the post World War Two national development policy - which saw among other things the construction of hydro-electricity schemes, dams and mines - combined with general prosperity and cold war sensibilities to keep the environment off mainstream political agendas for many years. Urban crisis in the late 1960s and early 1970s, growing regional decline and the general bankruptcy of liberalism as the Vietnam War drew disastrously towards its end saw the re-emergence of the environmental movement. In a heightened period of nationalism and with a growing interest in Australian history, cultural heritage was elevated in importance from its former lowly status. ${ }^{16}$ But this was a gradual process. Australia ICOMOS was not established until October 1976 and its Burra Charter, based on the 1966 Venice Charter, was adopted in 1979. ${ }^{17}$

Ironically, the formation of the Australian Conservation Foundation (AFC) in 1965 was a major marker of the reinvigoration of the environmental movement. But in a milieu driven by a desire to increase national economic growth the AFC adopted a conservative preference for 'controlled development'. ${ }^{18}$ Many environmental activists, however, were young urbanites who, radicalised by the student and anti-war movements, had taken to the streets to save inner city environments. In 1973 the AFC's executive was deposed and people such as Jack Mundey - communist, unionist and proponent of 'green bans' - were elected to form a new executive. ${ }^{19}$ Indigenous heritage, however, gained limited recognition until the 1980s. Aboriginal culture was generally caste as 'prehistoric'. ${ }^{20}$ But romantic notions of Indigenous heritage did not stop white supporters engaging with the land rights movement. The new environmentalism was closely linked to protest movements and social justice issues and it ignored traditional political party lines. ${ }^{21}$

One largely political response to growing environmental concerns by the McMahon Liberal Federal Government was the establishment in 1971 of a junior portfolio for the environment along with a tiny Office of the Environment. But it was 
not until the election of the Whitlam Labor Government in 1973 that serious attention was paid to creating a national heritage agency. A Committee of Inquiry chaired by Justice Robert Hope was formed in April 1973. The Hope Report's main recommendation was the establishment of a permanent, independent statutory authority which it wished to call the 'National Estate Commission'. This in part reflected global heritage language: UNESCO's Committee for the Protection of World Cultural and National Heritage spoke of an 'International Estate'. 22 The Hope Report also identified parts of the Constitution which could provide significant leverage in implementing heritage policies and aims.

Section 96 of the Constitution, which dealt with tied grants to states, could be used in this way. So too could powers relating to international trade and commerce as well as those concerned with export controls, notably via licences. This was especially relevant to forestry and mining. Approvals for the importation of foreign capital for development projects could impose conditions that protected or enhanced the environment. Section 51 of the Constitution also gave the Commonwealth powers to safeguard Indigenous heritage.$^{23}$ Eventually, however, powers relating to heritage protection were to be challenged by the lack of a clear definition of the 'National Estate'. This term ultimately and incorrectly came to be seen as describing a collection of places of 'national significance'. It was meant to encompass 'the things we want to keep,. ${ }^{24}$

Not long before the tumultuous sacking of the Whitlam Government in 1975, the Australian Heritage Commission Act was passed. It provided for the creation of the Australian Heritage Commission (AHC). Section 30 of the Act obliged all federal ministers and agencies to guarantee that nothing - from considerations about the sale of federal property to the issuing of export licences - would be done to adversely affect any place listed in the Register. ${ }^{25}$ Only when there was 'no feasible or prudent alternative' could a decision or action be made and even then impacts had to be minimised. This section, which was to plague the Commonwealth government, also allowed the $\mathrm{AHC}$ to comment on any such case at its own discretion. While a listing provided no direct protection to a place - and section 30 allowed only for coercion, not compulsion - the section required all such advice to be tabled in Federal parliament. The AHC's power to bring contentious heritage issues into the public domain made it potentially uncontrollable but this was not perceived clearly at the time of enactment. This power was amplified greatly in the 1980s when two decisions of the High Court of Australia - over the Murphyores and Tasmanian Dams cases boosted the constitutional powers of the Federal government vis a vis the environment. ${ }^{26}$ One controversial area that was highly visible in the mid 1970 s was land rights and the Fraser Government amended the Act to only allow the listing of Indigenous sites already on state or territory heritage lists. Unlisted sites could only be nominated by groups that gained Ministerial approval. ${ }^{27}$ One reading of such an action would see this as an attempt by the Federal government to minimise routes for adding legitimacy to land claims. 
The AHC was established on 9 July 1976. David Yencken was its first Chair. By 1978, six interim lists had been published proposing more than 6000 places for inclusion in the Register of the National Estate. This attracted 1000 objections requesting the removal of 470 places from the lists. ${ }^{28}$ Anyone or any group could lodge an objection. Some were extreme. At least one clash between a rural community and the Commission came close to violence. ${ }^{29}$ The Australian League of Rights, a right-wing organization which was especially supported in struggling rural and regional areas, played on anxieties and developed several conspiratorial theories about the AHC. One of the League's fronts was the Australian Heritage Society which attacked the Commission on a number of occasions. The League generally saw environmentalism as having been captured by centralists, socialists and collectivists who aimed to undermine the nation. ${ }^{30}$ Others agreed with this extreme position. Mining industrialist, pastoralist and 'self-made man' Lang Hancock cast the environmental movement as the 'Number One enemy of civilisation'. 'The main danger today', he railed in 1979 ,

resides in the environmentalist movement... I am referring to those subversives who, for personal gain or a lust for power, are desirous of breaking down what is left of our 'free enterprise' system entirely; these latter people, whose numbers are swelled by a great mass of unwashed, unspanked, dole-bludging dropouts, are threatening the lives and fortunes of the Australian community as it has never been threatened before. ${ }^{31}$

There were also inter and intra governmental clashes with the AHC. In answer, for example, to a question in Parliament in 1979 about lobbying by mining interests to dilute environmental protection mechanisms Prime Minister Malcolm Fraser insisted that the
Principles of the Heritage Commission are of great importance to Australia and this Government will maintain those principles to the fullest; but at the same time there are some elements of the Heritage Commission Act, as originally passed, which do come into conflict with other Acts and which could even stand in the way of matters which have been under full environmental examination. ${ }^{32}$

Section 30 of the AHC Act was simpler to utilize than provisions in the Environmental Protection (Impacts of Proposals) Act. And the Commission could and did act independently, at times frustrating Federal desires or embarrassing the Commonwealth Government. This occurred during the Ranger Inquiry into uranium mining in Kakadu. ${ }^{33}$ Thus the Commonwealth Government was added to the long list of the Commission's critics which include not only disaffected or anxious local but state and territory governments - particularly Queensland, Western Australia, Tasmania and the Northern Territory - Commonwealth Departments concerned 
about financial liabilities and industry bodies, notably the Mineral Sands Producers' Association, the Australian Mining Council, the Australian Coal Association and forestry interest groups. ${ }^{34}$ Even environmental groups, which were invariably from time-to-time upset by the outcomes of negotiations over contested places, became severe critics of the Commission.

After six years in operation, David Yenken observed of the AHC that:

Politics have dominated the whole of the Commission's life. There has hardly been a day when the Commission could relax and do its work without concern for some political threat or misunderstanding. ${ }^{35}$

Debates concerning conservation, particularly related to the natural environment, were to become even more combative during the 1980s. Major conflicts erupted, the most heated of which was the battle over the Gordon-below-Franklin dam proposal which came to a head in early 1983 not long after the threatened area was placed on the World Heritage List. ${ }^{36}$ Arguably the most renowned campaign in the environmental movement's history in Australia, and underlining the tug of war over states' versus federal rights, the Franklin Dam became a central issue in the March 1983 federal election and it contributed to the defeat of the Fraser government. ${ }^{37}$ Intense struggles were also to take place over the logging of old growth forest - primarily in south-eastern New South Wales - and wood chipping in north-eastern Tasmania, Western Australia's karri forests and in East Gippsland in Victoria.

Environmental activism, however, collided with a host of other developments. Unemployment - officially over ten per cent - was to be the main issue in the 1983 federal election. Economic growth in the broader region and a continuing dependence on mining and forestry exports drove governments to prioritise resource security for exporters and investors. The spectre of globalisation intimidated many at the coalface of commodity-based industry. And at the federal level, a corporatist Labor government embraced economic rationalism. In these contexts, it was inevitable that heritage conservation was to be primarily propelled by conflict. This was certainly the case with nominations for the Register of the National Estate. Most places, for example, were put forward for listing when they were perceived to be potentially vulnerable. Thus the entire process of negotiation was effectively predicated on disputation.

Nonetheless, for a while heritage conservation became so contentious and potentially damaging to political parties that the status of the federal portfolio for the environment became elevated. Before the 1980 s, only junior cabinet ministers twenty-one of them for the decade after 1972 - had been given this position. But from 1987 until 1991, Graham Richardson, Labor's leading strategist and numbers person, was handed the environment portfolio. ${ }^{38}$ The nature of heritage conservation was also challenged. Commenting in 1979 on the Register of the National Estate, 
Ray Whitmore, Chair of the AHC and Professor of Engineering at the University of Queensland, commented that

An interplanetary traveller landing in Queensland today and turning to the listings of the National Trust of Queensland or the Register of the National Estate for an appreciation of the life and achievements of her citizens since settlement would be presented with a strange picture. He would conclude that her forefathers lived in fine colonial homes, made banks and churches their principal monuments, invested in practically no public utilities, and hardly ever went to work. ${ }^{39}$

Three quarters of places in the Register were individual buildings. This reflected the dominance of architecture and aesthetics and the role of the National Trusts preoccupied as they are with grand homes and fine examples of architectural styles in initially building up the Register. Indigenous, industrial, multicultural, women's, working-class and various other types of heritage were severely underrepresented.

The historic environment was also poorly handled. This became evident as urban protests ignited mainly in the larger capital cities in response to developments booms in the 1980s. Conflict over the construction of Grosvenor Place in The Rocks, one of Sydney's premier historic precincts, was a prime example. ${ }^{40}$ Only three states had passed legislation dealing with the protection of the historic environment by the early 1980 s, a situation which remained largely unchanged ten years later. Victoria was the first to do so in 1974, pre-dating the AHC's 1975 act. But its provisions were limited, privileging the city and individual buildings over rural areas and moveable items while disregarding cultural precincts and landscapes. While the New South Wales Heritage Act of 1977 was much stronger it failed to have any significant impact for much of the 1980s due to the competing demands fuelled by the property boom and did not establish a register of significant places. The South Australian Heritage Act came into being in 1978 and, like its New South Wales' counterpart, was developed to function with state planning laws. Queensland's Cultural Record (Landscapes Queensland and Queensland Estate) Act of 1987 was denounced as being 'totally inadequate'. ${ }^{41}$ Effective heritage legislation would not exist across the States until the late 1990s and even then their provisions could be hampered by mechanisms such as ministerial veto.

A review of the Register of the National Estate was conducted in 1994. Historic places were still poorly represented in rural and remote areas. Indigenous places were found to be generally under represented and there were few listings for 'social value' or intangible heritage. ${ }^{42}$ Gradual attempts were made to address these problems. ${ }^{43}$ And the Commission worked towards making heritage practice more professional, systematic and scientific. ${ }^{44}$ Indeed, heritage conservation had by this time achieved a relatively high profile. This was reflected in a variety of ways: from the growth of commercial heritage products, paint schemes and project homes to heightened fears of preservation orders harboured by property owners. Heritage 
conservation could also win votes and even elections if handled carefully. ${ }^{45}$ This had again been demonstrated in the case of stage three of Kakadu National Park which had been 'managed' by allowing conservation zones - on 'clapped-out buffalo country ${ }^{46}$ - and mining to co-exist. But the balance was delicate and potentially dangerous. And it conflicted with other more pressing objectives.

The Labor federal government, lead by Paul Keating from 1990, became determined to 'get the environment off the front page'. ${ }^{47}$ This process commenced around the time of the 1990 election. After being re-elected, the Labor government shuffled its cabinet ministers and Graham Richardson and his newly found environmental sensibilities departed the environment portfolio which subsequently lost status. Resource security was positioned as a key policy aim to build a 'competitive Australia' and a Resource Assessment Commission Act was passed. ${ }^{48}$ Amendments, too, had been made to the AHC's act which, in one instance, gave the Minister power to review any place in the Register. Removal of a place from the Register was now possible. ${ }^{49}$ Duplication of responsibilities and poor coordination between state and federal agencies was also, and not unreasonably in some regards, put forward as an argument for streamlining conflict-ridden heritage processes. Conservatives especially pushed for the diminution of federal intervention though this position played down major differences towards heritage conservation between states and territories.

Even though the process of identification and assessment had become less reactive and placed on a more rigorous and seemingly 'scientific' footing listing remained no less contentious. Indeed, Commission powers to list places in the Register were still being seriously contested in the mid-1990s. A number of challenges to the Commission's processes for listing places in the Register were mounted in the Federal and High Courts initiated under the Administrative Decisions (Judicial Review) Act $1977 .{ }^{50}$ Among them was the challenge to the listing of the Sir Edward Pellew Islands and surrounds in the Northern Territory by Mount Isa Mines (MIM) Holdings in 1996. This was perhaps the most significant and sustained challenge to the Commission's functions, specifically over the notion of objective criteria for defining the National Estate. And it was subtly encouraged by the Federal government.

Located in waters south east of Darwin near Borroloola, the islands were deemed to be primarily significant for their largely undisturbed ecosystems and wildlife. Mining giant MIM Holdings, however, had extensive investments in and around the islands and intended to develop plans to commence the open-cut McArthur River mine. MIM was looking for international partners to proceed. ${ }^{51}$ The islands were placed on the Commission's Interim List in April 1988. Objections from MIM, however, were spurred by its successful negotiation of a joint $\$ 250$ million venture with a consortium of Japanese companies led by Nipon Mining and Metals in 1991.

Chair of MIM, Sir Bruce Watson, publically accused the Commission 'of rigidity, incompetence and intellectual softness, which', he claimed, 'typified this country's 
environmental preservationist mindset'. ${ }^{52}$ Essentially, MIM argued that a place could not be listed in the register unless it answered the description in section 4 of the Australian Heritage Commission Act as a matter of objective fact. It was particularly concerned to avoid future Federal interference in its activities in the broader area and to generally signal to potential investors in Australia that their investments would not be exposed to risk based on the 'subjective' determinations of the Australian Heritage Commission.

The economic potential of the MIM venture saw it designated as a 'major project' by the Federal Government which gave it priority for approval procedures. The period of assessment of MIM's objection to listing allowed under the Act was also extended by the Minister, Ros Kelly, to November 1993. MIM's final submission was received by the Commission in May 1994 but the Commission ultimately decided to place a reduced area incorporating the islands, seagrass beds, mangroves and mud flats of the Interim Listed site in the Register. MIM lodged a successful challenge to this decision in the Federal Court in February 1995. In March 1997, the High Court overturned the decision and reaffirmed the Commission's role. The five judges found that the Commission's power to list a place in the Register depended upon whether or not such a place so qualified, as defined in its Act, using a degree of 'value judgment'. But by then the Howard Coalition Government had been elected and the Commission's days were numbered. ${ }^{53}$

\section{FEDERAL HERITAGE LEGISLATION IN THE YEAR OF THE BUILT ENVIRONMENT}

On 1 January 2004 - the year of the built environment - new federal heritage legislation came into effect. The Environment Protection Biodiversity Conservation Act 1999 created the National Heritage List, for places with outstanding heritage value to the nation, and the Commonwealth Heritage List, which accommodated sites of exceptional heritage worth owned by the Commonwealth government. ${ }^{54}$ The Register of the National Estate, which has no protective mechanisms, was retained. Australian World Heritage listings - of which there were fifteen - were unaffected by the new provisions. (See Table 1.)

The act also brought into existence the Australian Heritage Council, a seven member advisory body, which replaced the AHC. Its principal responsibilities were to assess nominations for the National Heritage List and the Commonwealth Heritage List; promote heritage identification, assessment and conservation; and compile and monitor the Register of the National Estate. ${ }^{55}$ The Council's role was to be purely advisory. Ultimate decision-making power rested with the responsible Minister. The first appointments to the Council were BHP Billiton ${ }^{56}$ Chief Executive Officer Tom Harley (Chair), former senior public servant Roger Beale, Jane Lennon, Denis Saunders, Michael Kennedy, Gaye Sculthorpe and Richard Walley. All but Kennedy and Walley had been Commissioners on the Australian Heritage Commission.

A number of problems were evident in the legislation and its implementation. It was not enough to simply meet the criteria for an item to be placed on a list. Thresholds of significance which compared similar places were used to establish 
whether a site was of 'outstanding' heritage value. Such fuzzy determinations left room for political manoeuvrings. Even if listed it 'is the national heritage values of a place that are recorded in the list and it is these values, and not necessarily the entire place itself, that are protected. ${ }^{57}$ Affected property owners and indigenous people with particular interests could comment on this process. But input from the public was entirely reliant on ministerial discretion. ${ }^{58}$

TABLE 1

\begin{tabular}{|c|c|c|c|c|}
\hline & $\begin{array}{l}\text { World } \\
\text { Heritage }\end{array}$ & $\begin{array}{l}\text { National } \\
\text { Heritage }\end{array}$ & $\begin{array}{l}\text { Commonwealth } \\
\text { Heritage }\end{array}$ & $\begin{array}{l}\text { Register of the } \\
\text { National Estate }\end{array}$ \\
\hline $\begin{array}{l}\text { Administration } \\
\text { of legislation }\end{array}$ & Minister $^{1}$ & Minister & Minister & $\mathrm{AHC}^{2}$ \\
\hline Nomination & $\begin{array}{l}\text { Australian } \\
\text { Government }\end{array}$ & $\begin{array}{l}\text { Anyone } \\
\text { Minister } \\
\text { AHC }\end{array}$ & $\begin{array}{l}\text { Anyone } \\
\text { Minister } \\
\text { AHC }\end{array}$ & Anyone \\
\hline Values & $\begin{array}{l}\text { Outstanding } \\
\text { Universal }\end{array}$ & $\begin{array}{l}\text { Outstanding } \\
\text { to nation }\end{array}$ & $\begin{array}{l}\text { Commonwealth } \\
\text { heritage }\end{array}$ & National Estate \\
\hline Types of value & $\begin{array}{l}\text { Natural } \\
\text { Cultural }\end{array}$ & $\begin{array}{l}\text { Natural } \\
\text { Indigenous } \\
\text { Historic }\end{array}$ & $\begin{array}{l}\text { Natural } \\
\text { Indigenous } \\
\text { Historic }\end{array}$ & $\begin{array}{l}\text { Natural } \\
\text { Indigenous } \\
\text { Historic }\end{array}$ \\
\hline Criteria & $\begin{array}{l}\text { World Heritage } \\
\text { Committee }\end{array}$ & EPBC Act ${ }^{3}$ & EPBC Act & AHC Act \\
\hline Assessment & $\begin{array}{l}\text { World Heritage } \\
\text { Bureau }\end{array}$ & $\mathrm{AHC}$ & $\mathrm{AHC}$ & $\mathrm{AHC}$ \\
\hline Decision on listing & $\begin{array}{l}\text { World Heritage } \\
\text { Committee }\end{array}$ & Minister & Minister & $\mathrm{AHC}$ \\
\hline Tenure & $\begin{array}{l}\text { All can be listed } \\
\text { but unaffected } \\
\text { by listing }\end{array}$ & $\begin{array}{l}\text { All can be listed } \\
\text { but unaffected } \\
\text { by listing }\end{array}$ & $\begin{array}{l}\text { Commonwealth } \\
\text { only but unaffected } \\
\text { by listing }\end{array}$ & $\begin{array}{l}\text { All can be listed } \\
\text { but unaffected } \\
\text { by listing }\end{array}$ \\
\hline $\begin{array}{l}\text { Obligations } \\
\text { and approvals }\end{array}$ & $\begin{array}{l}\text { No action } \\
\text { that may } \\
\text { significantly } \\
\text { impact on values; } \\
\text { Minister }\end{array}$ & $\begin{array}{l}\text { No action } \\
\text { that may } \\
\text { significantly } \\
\text { impact on values; } \\
\text { Minister }\end{array}$ & $\begin{array}{l}\text { No action } \\
\text { that may } \\
\text { significantly impact } \\
\text { on environment } \\
\text { including values; } \\
\text { Minister }\end{array}$ & $\begin{array}{l}\text { Take regard } \\
\text { of information } \\
\text { in the Register; } \\
\text { Minister }\end{array}$ \\
\hline
\end{tabular}

Notes

1. Minister for the Environment and Heritage.

2. Australian Heritage Council.

3. Environmental Protection Biodiversity Conservation Act (1999).

Source: Department of Environment and Heritage, Factsheet, no 21.

By mid July 2004 there were 336 items on the Commonwealth Heritage List. The National Heritage List included Anzac Cove at Gallipoli and Port Arthur in Tasmania. Ironically, both were sites of massacre but they were incorporated into the national 
story of 'heroic and unique achievement against the odds'. Gallipoli, where 8141 Australian soldiers were killed and over 18,000 wounded during World War One, concerned remembering heroic warriors. The Port Arthur penal settlement, where in 1996 thirty-five tourists were killed and dozens wounded by a shooter, romanticised what was a cruel colonial place of secondary punishment while presenting a stereotype of oppressed convicts amid 'impressive architecture and delightful gardens' ${ }^{59}$ Both were also uncontested sites. When Dr David Kemp, then Minister for the Environment and Heritage, announced that Port Arthur was to be nominated for listing, Greens Senator Bob Brown attacked the federal government for 'taking the soft option'. ${ }^{60}$ Brown claimed that, in Tasmania, Recherche Bay and Tarkine were more important. Recherche Bay, the site of the remnants of a 212-year-old French observatory and gardens, was to be logged. ${ }^{61}$ The Tarkine wilderness, a sixty-five million-year-old temperate rainforest, was to be opened to logging with the threatened removal of a twenty year moratorium on that industry in the area. ${ }^{62}$ Campaigns were launched to secure protection for both sites.

The first three entries on the National Heritage List were made on 16 July 2004. They were Budj Bim National Heritage Landscape at Lake Condah in Victoria's south west where the Gunditjmara people had, thousands of year ago, constructed a complex system of weirs, water races, channels and traps to catch fish; Dinosaur Stampede National Monument at Lake Quarry near Winton, Queensland; and the Royal Exhibition Building National Historic Place in Melbourne. These sites were undoubtedly important but their choice was telling. Budj Bim reinforced the portrayal of Indigenous people as being 'of the past' and the extreme marginalisation of postinvasion Aboriginal experience. Fringe settlements, locks ups and racially segregated swimming pools and cinemas disappear in this narrative. Dinosaurs are seldom controversial. And the Royal Exhibition building symbolised the triumph of aesthetics, the grand and the comfortably iconic. Conservative revisionism - which includes excluded and marginalised groups in national stories without introducing contestation and social divisiveness - currently dominates official heritage conservation in Australia. And process is now arbitrary. But there remains an entrenched resistance in many quarters to publicly acknowledge that heritage conservation is, as much as anything else, political. This was powerfully demonstrated in 2005 when the Commonwealth Productivity Commission released its draft report on historic heritage conservation in Australia. ${ }^{63}$ Directly reflecting the Federal Government's conservative ideology, the Commission's key finding included the need to bring to an end 'an over reliance on prescriptive regulation', to curtail or limit regulations that restricted 'development and use', to protect 'property rights and values' and to minimise heritage listings. This marked the final phase of the corporatisation of heritage.

\section{Endnotes}

\footnotetext{
${ }^{1}$ Geoffrey Bolton, Spoils and Spoilers: Australian make their environment, Allen and Unwin, Sydney, 1981, pvii.
} 
${ }^{2}$ See Jennifer Cornwall and Paul Ashton, 'Times of Hope: A history of the Australian Heritage Commission', manuscript, Sydney, 2005. This history was commissioned by the AHC but the federal Department of Environment and Heritage has not proceeded with publication.

${ }^{3}$ Quoted in Drew Hutton and Libby Connors, A History of the Australian Conservation Movement, Cambridge University Press, Melbourne, 1999, p3.

${ }^{4}$ Sheridan Burke, 'The State Heritage Inventory Project', in Terry Kass (ed), The Role of History in Conservation Work, PHA NSW Inc, monograph series no 1, Sydney, 1993, p17.

${ }^{5}$ Tourism generally accounted for $4.2 \%$ of GDP in 2002-3. Gross value added was $\$ 26$ billion. See

Commonwealth of Australia, Year Book Australia, 'The Economic Contribution of Tourism'.

${ }^{6}$ See for example, Sue Rosen, 'Luna Park: Just for Fun?', Public History Review, vol 1, 1992, p61 and Chris Johnston, What is Social Value? A Discussion Paper, Australian Heritage Commission, technical publication series, no 3, the Commission, 1992.

${ }^{7}$ See, for example, Denis Byrne, 'The Archaeology of Disaster', Public History Review, vol 5/6, 1996-77, pp17$18 \mathrm{ff}$.

${ }^{8}$ New South Wales Bicentennial Council, Meeting no 5, 12 February 1982, Agenda Papers, NSW State Records.

${ }^{9}$ Tony Birch, '"Black armbands and white veils": John Howard's moral amnesia', Melbourne Historical Journal, no $25, \mathrm{p} 9$.

${ }^{10}$ The Australian, 19 November 1996.

${ }^{11}$ See Guy Hansen, 'White Hot History: the review of the National Museum of Australia', Public History Review, vol 11, 2004, pp39-50.

${ }^{12}$ For a broad definition of heritage see Chris Healy, "Race Portraits" and vernacular possibilities: Heritage and Culture', in Tony Bennett and David Carter (eds), Culture in Australia: Policies, Publics and Programs,

Cambridge University Press, 2001, pp278-9.

${ }^{13}$ The first was the New South Wales Native Bird Protection Act 1893.

${ }^{14}$ RolandBreckwoldt, The Dirt Doctors: A Jubilee History of the Soil Conservation Service of NSW, Soil Conservation Service, Sydney, 1988, chs 2 and 3.

${ }^{15}$ Susan McClean, '"Progress the Iconoclast": Campaigns, Ideologies and Dilemas of Historic Building Preservation in New South Wales, 1900-1939', Public History Review, vol 7, 1998, pp25-42.

${ }^{16}$ Australia signed the Convention for the Protection of World Cultural and Natural Heritage on 22 August 1974 and joined the International Centre for the Study of the Preservation and Restoration of Cultural Property (Rome Centre) in June 1975. In terms of the natural environment, in May 1973 the Commonwealth joined the International Union for Conservation of Nature and Natural Resources. It signed the Convention on International Trade in Endangered Species of Wildlife and Flora in September 1973.

${ }_{17}^{17}$ Peter Marquis-Kyle and Meredith Walker, The Illustrated Burra Charter, ICOMOS, Sydney, 1992, p8.

${ }^{18}$ Drew Hutton and Libby Connors, A History of the Australian Environmental Movement, Cambridge University Press, Melbourne, 1999, pp106-8; 135-6.

${ }^{19}$ Meredith Burgman and Verity Burgman, Green Bans, Red Union: Environmental activism and the NSW

Builders Labourers' Federation, UNSW Press, Sydney, 1988, p70.

${ }_{20}$ Denis Byrne, 'The Archaeology of Disaster', Public History Review, vol 5/6, 1996-7, p18ff.

${ }^{21}$ See, for example, Verity Burgman, Power and Protest: Movements for Change in Australian Society, Allen and Unwin, Sydney, 1993, chapter 3.

${ }^{22}$ Graeme Davison, 'The meanings of "heritage"', in Graeme Davison and Chris McConville (eds), A Heritage

Handbook, Allen and Unwin, Sydney, 1992, pp2-3.

${ }_{23}$ National Estate (Hope Report), Australian Government Publishing Service, Canberra, 1974, pp166-7.

${ }^{24}$ ibid, p30.

${ }^{25}$ Similar general protection was available via an Environment Impact Statement (EIS) under the Environment Protection (Impact of Proposals) Act (1974). Section 30 provided added protectioin for items in the Register of the National Estate.

${ }_{26}$ Michael coper, The Franklin Dam Case, Butterworths, North Ryde, 1985, p25.

${ }^{27}$ Australian Heritage Commission, Annual Report, 1976-7, p11.

${ }^{28}$ ibid, 1978-79, p10.

${ }^{29}$ Cornwall and Ashton, op cit, chapter 3.

${ }^{30}$ Andrew Moore, The Right Road? A History of Right-wing Politics in Australia, Oxford University Press, Melbourne, 1995, p72.

${ }^{31}$ Quoted in A. Gilpin, The Australian Environment: 12 Controversial Issues, Melbourne, 1980, p.46.

${ }^{32}$ Hansard, 22 February 1979, p257.

${ }^{33}$ See for example Colin Michael Hall, Wasteland to World Heritage: Preserving Australia's Wilderness,

Melbourne University Press, Melbourne, 1992, pp207-210; 226.

${ }_{34}$ Hodges Report, ppiii; 76-7.

${ }^{35}$ David Yenken, 'Jewels and Old Shoes: Recollections of the Australian Heritage Commission', Historic

Environment, vol 1, no 4, p1.

${ }^{36}$ The Australian, 14 December 1982

${ }^{37}$ Wilderness Society (Australia), The Franklin Blockade, Wilderness Society, Hobart, 1993.

${ }^{38}$ Sydney Morning Herald, 14 July 1987, p15. 
${ }^{39}$ Ray Whitmore, 'Our Engineering Heritage', Institute of Engineers Australia (Queensland Division), Technical Papers, vol 20, no 6, April 1979, quoted in Australia's National Estate: The Role of The Commonwealth, AHC Special Heritage Publication Series, no 1, Australian Government Publishing Service, Canberra, 1985, p126. ${ }_{40}$ Sydney Morning Herald, 19 September and 20 November 1985. Generally, see Paul Ashton, The Accidental City: Planning Sydney Since 1788, Hale and Iremonger, Sydney 1993 and Max Kelly and Chris McConville,

'Down by the Docks', in Davison and McConville, op cit, pp91-114.

${ }^{41}$ Sheryl Yelland, 'Heritage legislation in perspective', in Davison and McConville, op cit, p58.

${ }^{42}$ AHC, Annual Report, 1994-5, p13. See also Chris Johnston, What is Social Value?: A Discussion Paper, AHC, Technical Publications Series, no 3, AGPS, Canberra, 1992.

${ }^{43}$ For example, through publications such as Migrant Heritage in Australia: how to find it, AHC, Canberra, 1997.

${ }^{44}$ Graeme Davison, The Use and Abuse of Australian History, Allen and Unwin, Sydney, 2000, pp125-6.

${ }^{45}$ Phillip Toyne, The Relucant Nation: Environmental Law and Politics in Australia, ABC Books, Sydney, 1994, p138.

${ }_{46}$ Sydney Morning Herald, 17 September 1986.

${ }^{47}$ Sydney Morning Herald, 25 June 1994, p5.

${ }^{48}$ AHC, Annual Report, 1990-1, p48.

${ }^{49}$ ibid.

${ }^{50}$ One of the cases, over the Perth Airport Bushland, was settled out of court on the basis that the Commission did not in any way concede that its decision to list involved any error in law. An application in the Federal Court in relation to Hesketh House in Brisbane was adjourned pending the outcome of proceedings in the Queensland Supreme court about the place

${ }^{51}$ AHC file no 7/4/16/25. See also Business Review Weekly, 11 June 1993.

${ }^{52}$ Australian Financial Review, 6 February 1991.

${ }^{53}$ Cornwall and Ashton, op cit, chapter 8.

${ }^{54}$ Department of Environment and Heritage, Fact Sheet 17,

www.deh.gov.au/heritage/publications/factsheets/fact17.html

Department of Environment and Heritage, 'Australian Heritage Council Appointed', press release, 18 February 2004.

${ }^{56}$ On BHP Billiton's environmental record, see Lise Rist, 'BHP Billiton and their environmental effort: a genuine attempt or clever public relations', in Mining Australia, 2005.

${ }^{57}$ Department of Heritage and the Environment, 'What does National Heritage listing mean?', DHE, Fact Sheet 6. ${ }^{58}$ ibid.

${ }^{59}$ Port Arthur web site homepage: www.portarthur.org.au

${ }^{60}$ Doorstop interview, Cascade Female Factory, Hobart, Tasmania, 20 April 2004, transcript, Department of Heritage and the Environment: www.deh.gov.au/minister/env/2004/tr20apr04.html

${ }^{61}$ ABC News Online, 2 December 2004.

${ }^{62}$ www.wwf.org.au/News_and_information/News_room/viewnews.php?news-id=57

${ }^{63}$ Productivity Commission, Conservation of Australia's Historic Heritage Places, draft report, Canberra,

December 2005: quotations are at pxvi. 